\title{
Article \\ Striving to Be Different but Becoming the Same: Creativity and Destination Brands' Promotional Videos
}

\author{
Tjaša Alegro *(D) and Maja Turnšek (D)
}

Faculty of Tourism, University of Maribor, Cesta prvih borcev 36, 8250 Brežice, Slovenia; maja.turnsek@um.si

* Correspondence: tjasa.alegro1@um.si

\begin{abstract}
Social networks have become an important supplement to traditional forms of marketing channels for destination branding. YouTube is believed to be one of the most influential social media and video sharing platforms. Its visual character, informal setting and address of the youth segment would expectedly mean a high level of creativity in the process of destination branding. By means of qualitative analysis of what are considered to be the best videos as self-selected by the European destination management organizations (DMOs), we wished to ascertain how creative these best case examples really were. The results show that the videos are extremely similar, with the most common type a "collage" of only loosely connected visuals with rare elements of storytelling or humor as the most typical creative approaches. While following the desire to show the diversity of a destination, the destination branding videos paradoxically become a collection of similar visual images and thus fail to contribute to the differentiation of the destination brand. The results show that future advice to practitioners of destination marketing for YouTube is to go beyond the typical "collage" genre of a destination marketing video and focus more on storytelling, humor and especially the most difficult step in the destination branding: strategically focusing on the smaller number of specifics that differentiate a destination rather than on the multitude of the highly diverse experiences.
\end{abstract}

Keywords: creativity; destination branding; YouTube; storytelling; humor

check for

updates

Citation: Alegro, T.; Turnšek, M. Striving to Be Different but Becoming the Same: Creativity and Destination Brands' Promotional Videos. Sustainability 2021, 13, 139. https:// dx.doi.org/10.3390/su13010139

Received: 22 November 2020 Accepted: 22 December 2020 Published: 25 December 2020

Publisher's Note: MDPI stays neutral with regard to jurisdictional claims in published maps and institutional affiliations.

Copyright: () 2020 by the authors. Licensee MDPI, Basel, Switzerland. This article is an open access article distributed under the terms and conditions of the Creative Commons Attribution (CC BY) license (https: / / creativecommons.org/ licenses/by/4.0/).

\section{Introduction}

In striving for creating ever new and different experiences, tourism has recently been identified as one of the creative industries [1]. Creativity transforms traditional tourism and integrates it more and more into the everyday life of the destination. Creative tourism reflects the link between tourism and different destination design strategies, including promotion [2].

In this research we focus on the question of creativity in destination branding on YouTube. As tourism is becoming more and more characterised as a creative industry, the competition amongst the destinations in promotion is growing and platforms such as YouTube are posing great challenges to finding ways to stand out. It is thus important to analyse the extent to which national destination marketing is responding to these challenges with creative advertising of its own in order to identify both the general trends and the cases of best practice.

In consumer advertising, psychological differentiators, such as creativity, are often used to maximize the impact of advertising [3]. El-Murad and West [4] claim that creativity is the most important element in advertising to be successful. We associate creative ads with increased brand awareness and consumer appeal [5]. Creative advertising is said to be more memorable, receives more attention, provides the opportunity to spend less money on advertising (e.g., guerrilla advertising) and provides an opportunity to build a fandom related to the creativity of the product and its advertising [6]. In the media world, creativity in advertising has gained importance as a means of overcoming consumer perceptual barriers to gain their attention. In the advertising industry, overcoming this barrier is emphasized by the terms "unique sales offer" and "great idea" [7]. 
The aim of this paper is, on the one hand, to analyse the creativity of destination branding on YouTube and on the other hand to identify the common, or typical: what Turnšek and Janecek [8] term "destination imagery" on YouTube and what others term as a predetermined structure evoked by the ad theme: similarities of the ads of the same product forming a category or schema, that can even be termed as an advertising genre [9] of destination promotion.

\subsection{Destination Branding, YouTube and the Need for Creativity}

Pike and Page [10], summarize that destination marketing is now one of the pillars of future growth and sustainable development of tourism destinations in a globalized and competitive market, such as tourism. Destination management organizations (hereinafter referred to as DMOs) in charge of destination marketing, usually funded by national or local governments, are considered to be the main drivers of development to attract tourists to the destination [11]. The tourism industry is a large sector, characterised by intense competition among destinations. The goal of DMOs is to be as competitive as possible in building a positive and well known destination image and attracting guests [12,13]. Selecting the right marketing channels and tailoring the message to these channels is of upmost importance in these endeavours.

According to Perrin [14], 90\% of young Americans between the ages of 18 and 29 use social media. There is a growing body of research on the use of social media in tourism-How these channels are used to disseminate information, enrich tourism experiences and market tourism destinations [15]. According to Leung et al. [16] tourism organizations use social media primarily in the areas of marketing, management, communication and product distribution. The main goals of social media marketing activities are to attract new customers, increase sales, reinforce word of mouth communication about a destination, and create loyal customers [17]. They have become an important element of destination organizations' marketing strategies, especially in times of financial downturn, as they are tools that reach global audiences even with limited resources [18] and affect brand awareness in particular $[19,20]$.

Advances in multimedia technology have led to a tremendous increase in the volume of videos available [21]. Babin and Burns [22] emphasize the importance of visual content, stating that, for example, an advertisement containing more visual content has a more positive influence in promoting image creation and relationship to the product as well as to the brand. People can quickly perceive and understand complex visual scenes that contain a great deal of visual information, such as movies or short videos, and can still easily identify aspects of scenes and even remember some of them for a long time [23]. Dehghani et al. [24] analysed the YouTube advertisements that appear for example at the beginning of a video. Their results showed that YouTube ad valuation strategies were positively related to brand awareness, which also affected the perceived usefulness of YouTube and subsequent buying behaviour. The results further showed that fun, information and personalization are the strongest positive drivers, while irritation is expected to be negatively related to perceptions of advertising on YouTube.

Uşaklı, Koç and Sönmez [25] analysed the social media use of 50 European national DMOs and concluded that the most frequent major themes projected by DMOs in their social media postings were natural attractions (48\%), cultural attractions $(12.5 \%)$, historical attractions (8.5\%), local cuisine (6.4\%), and recreation facilities $(5.2 \%)$. These major themes accounted for over $80 \%$ of all posts in their analysed sample. They also discovered that despite the popularity of YouTube as a destination marketing channel, the analysed DMOs are less active in using this channel. Uşaklı et al. [25] explain this result by the fact that compared to other social media, it takes longer to produce a promotional video.

We argue here that destination branding on YouTube calls for a more creative approach than traditional television advertising, not only because of the extreme amount of content available, but also because of at least three other distinct reasons. The first reason is the advertising model of YouTube versus traditional television advertising. As Turnšek 
Hančič et al. [26] explain, YouTube's advertising model makes an important difference for tourism marketing. The traditional television advertising included "pay per eyeballs" approach - the price of an advertisement is defined by the number of viewers reached. Google, YouTube's owner, however, was amongst the leading pioneering champions of the "pay per click" advertising. In the traditional model the media house is not affected by the quality and success of the advertisement (it charged the same amount regardless of whether the advertisement was of poor or high quality). In the "pay per click" model, however, the media house benefits more by those advertisements that generate greater amounts of "clicks" - Thus giving primacy to the more successful cases. YouTube's "pay per click" advertising business model therefore puts greater pressure on the advertisers to continuously strive to find more attractive and creative advertising campaigns since they need to compete with other advertisers for advertising salience.

The second reason is in the potential "viral" spread of especially creative and outstanding advertisements. Videos are influential image creators of both brands and destinations, amongst other also because of the "viral" nature of using websites such as YouTube [27,28]. The "holy grail" of a successful YouTube campaign is in achieving outstanding numbers of views via sharing amongst users-A prominent example would be the Metro Trains Melbourne campaign "Dumb Ways to Die", created to communicate rail safety. It has reached over 316 million views via highly creative inclusion of humor [29].

Finally, and connected to its viral potential, YouTube is the prime channel of "participatory culture" [30], where the users express their own creativity. This is for example seen through popularity of phenomena such as "flash mobs"—Public gatherings where participants perform seemingly pointless acts in a short amount of time and then disperse again. Molnár [31], analysed 200 flash mobs around the world and claimed that YouTube proved to be the most comprehensive source in this endeavour and the prime entry point into the world of flash mobbing because most of the available raw data on flash mob events is visual. Another prominent example is the prominence of so called "memes" on YouTube-Users taking on the format of a specific original video and publishing their own creative expressions with variations and changes made to the original, most often including fun and entertaining content [32] but often also content with serious political messages expressed in fun and creative ways [8].

YouTube is thus a harsh marketing space for DMOs. On the one hand it affords all the benefits of visual content, potentially reaching millions of viewers and viral spread. On the other hand, the YouTube audiences are highly dispersed, self-navigating and primarily expect creative expressions amidst largely entertaining content, rewarding only those that are able to prominently stand out with their advertising creativity.

\subsection{Challenges of Analysing Advertisement Creativity on YouTube}

Torrance [33], the father of modern research on creativity, claims that if we want to look at creativity scientifically, it must be defined in such a way that it allows for objective perception and measurement to be consistent with shared historical use. Torrance found definitions that are formulated by product (innovation and discovery, for example) and others by process, by person, or by conditionality. Production of something new, however, is included in almost every definition. Creativity in advertising is generally defined as novelty and refers to a performance that is unusual or different. Advertising creativity is intended to promote both originality and innovation [34]. El-Murad and West [4] define creativity in advertising as a process of representing a product in a fresh way by establishing new and meaningful connections between unrelated things, while still preserving relevance and trust in the message.

When evaluating visual elements, these are highly polysemantic, so it is essential to have the term "visuality" in mind which means "how we see things, how we understand it and what we think this means" [35]. According to Jordanous [36], there is a wide variety of difference in people's perception of what is creative and attribute creativity to a wide variety of factors. Similarly, Lubart (1999) [37], in his intercultural studies, 
finds that not all cultures agree on what creativity means. According to Kripendorff [38], analysts, when faced with a new situation in content analysis in which they cannot rely on previously established theories and past research, they rely on personal knowledge and on their expertise. So, to assess creativity, it is necessary to know the content and have enough expertise in the field we are evaluating [39]. Likewise, experts are increasingly leaning towards novelties and unknowns within the frameworks they are familiar with [40]. Therefore, the expert analysis method is often used to assess creativity.

In an attempt to define and measure creativity quantitatively, Guilford [41] identifies four dimensions of creativity that are still nowadays the foundation of creativity research (for example in the classic "Guilford's Alternative Uses Task"): (a) fluency: number of ideas, (b) flexibility: number of different ideas (ideas in different categories), (c) originality: number of ideas that are infrequent in comparison to others' ideas and (d) elaboration: the extent of detail in the ideas. The list of dimensions and application to the field of marketing grew with later research, as did the complexity of their definitions and measurement together with their overlapping. Smith and Yang [42], for example, define a creative ad as both divergent (i.e., novel or unusual) and relevant. They added dimensions of resistance to premature closure, unusual perspective, synthesis, empathetic perspective, provocative questions, future orientation, humor, rich and colorful imagination, fantasy and expression of feelings and emotions. Reinartz and Saffert [6] added synthesis and artistic value. Ang and Low [43] identified novelty, meaningfulness, emotional content while Smith et al. added four dimensions, all extending the dimension of elaboration [44]. Since all of these dimensions are overlapping with the original four dimension and due to the complexity of the video material we narrowed the below-presented research to only four of the original dimensions and aimed at applying these dimensions to the specific context of YouTube destination branding.

\section{Materials and Methods}

Winning creative awards and achieving top results in creative rankings have become the key promotion tools for advertising industry. Using a sample of 108 campaigns, Kúbler and Proppe [45] identified innovativeness and the integration of multiple channels as the key drivers of creativity award success. In the plethora of destination marketing as available on YouTube we turned to a creative awards competition in order to select what the DMOs deem as their own best video campaigns.

We sampled YouTube destination branding videos from the UNWTO Tourism Video Competition that took place from 12 August to 15 September 2017 [46]. The contest called for outstanding promotional videos. Therefore, we assumed that the participating DMOs chose videos they thought were the best example of presenting their destination. Altogether 63 national DMOs participated in the competition, with 61 videos still being available at the time of sampling and archiving the material.

In this paper we aimed to apply four classical dimensions of creativity as identified by Guilford [41], and later applied to advertisement contexts by various authors [6,7]. We narrowed the research to only four of the original dimensions and operationalised them at the two units of analysis: the level of one video and the level of video sequences within a video. The four dimensions were: (a) fluency-Number of ideas: measured as video sequences with a specific value proposition (reasons for visiting a destination), presented within one video, (b) flexibility: the number of different categories of value propositions within one video, (c) originality: the number of sequences showing value propositions that are infrequent-Unique to a specific destination relatively to other videos, and finally (d) elaboration is the extent of detail with which value propositions are presented.

We performed a combination of qualitative and quantitative analysis of videos. The quantitative analysis was first focused on the smallest units of analysis: sequences of value propositions as transcribed in textual form for each of the 61 videos. In the second step we employed qualitative analysis as a means for inductively identifying main categories of video sequences and main thematic video types. 
An example of video transcription and coding is presented below (Table 1). The first variable measured at the level of the smallest units was fluency: the number of sequences identified within a video. The second variable was flexibility: number of different categories of value propositions.

Table 1. An example of coding, case of Slovenia, video: "Slovenia. Make new memories."

\begin{tabular}{|c|c|c|c|c|}
\hline $\begin{array}{l}\text { Textual Transcription of Video Sequences: } \\
\text { Value Propositions Identified in the Video }\end{array}$ & $\begin{array}{c}\text { Fluency: } \\
\text { Number of Value } \\
\text { Propositions }\end{array}$ & $\begin{array}{l}\text { Categories and } \\
\text { Number of } \\
\text { Sequences per } \\
\text { Category }\end{array}$ & $\begin{array}{l}\text { Flexibility: } \\
\text { Number of } \\
\text { Categories }\end{array}$ & $\begin{array}{l}\text { Main Thematic } \\
\text { Type }\end{array}$ \\
\hline 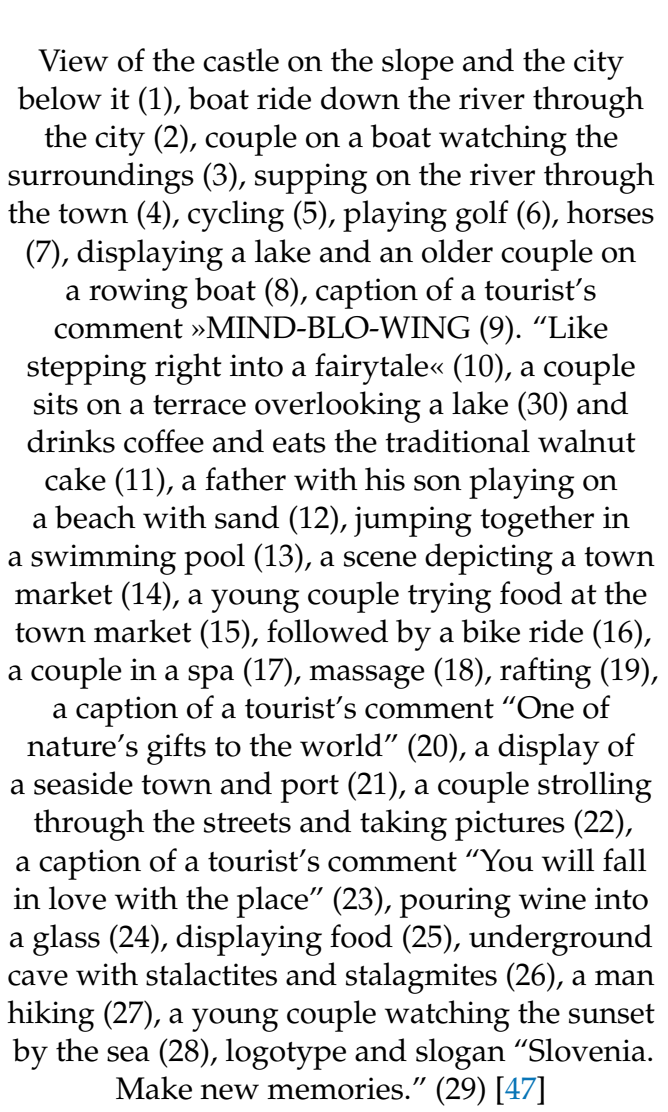 & 29 & 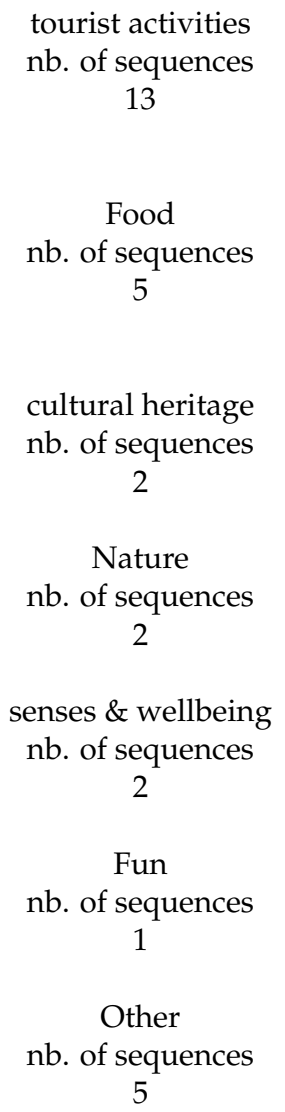 & 7 & Activities \\
\hline
\end{tabular}

After analysing fluency and flexibility, we identified the main thematic types of the videos. Based on the textual description of value propositions identified in the video we performed a thematic analysis of the text, which is a qualitative method for discovering a collection of topics or levels of sampled response or meaning in the data. The method depends on researcher's judgment and sufficiently loose rules [48]. Braun and Clarke [48] described the indicative phases of the thematic analysis that we hereby followed: (a) introducing the researcher to the data, (b) generating initial codes, (c) searching for topics, (d) reviewing topics, (e) defining and naming topics, (f) producing a report.

We identified 5 main thematic types of videos: (a) activities, (b) emotions, (c) heritage, (d) mixed, (e) indefinable. For example, the video of Slovenia is classified as a type "activities". The textual transcription of the video (Table 1) shows a number of activities that tourists are invited to do when visiting Slovenia, e.g., cycling, playing golf, drinking coffee and eating the traditional walnut cake, playing on a beach with sand, jumping in a swimming pool, etc. and the video is therefore classified in this broad "activities" thematic type. 


\section{Results and Discussion}

\subsection{Fluency and Flexibility: "Our Destination Has so Much to Offer! Ours Too!"}

Within advertising creativity research, the dimension of meaningfulness [43] has been introduced in order to point out that the advertisement not only has to rely on a novel communication approach (that is divergent from existing forms of communication), but the message also has to convey product-related information relevant to the customer. "This means that the overall idea, the message, and the information about the advertised product must convey a singular message that is relevant to the targeted customer" [45]. The singular message that the destination promotional videos are trying to convey is "visit our destination" and as such we can judge all of the videos as inherently meaningful. However, the number of reasons on as to why to visit (value propositions and their categories) differ amongst the videos. The results are presented in Table 2.

Table 2. Average fluency and flexibility of analysed videos $(\mathrm{N}=61)$.

\begin{tabular}{ccc}
\hline & Fluency (nb. of Value Propositions) & $\begin{array}{c}\text { Flexibility (nb. of Categories } \\
\text { of Value Propositions) }\end{array}$ \\
\hline Mean & 23.5 & 5.0 \\
\hline Std. Deviation & 10.2 & 1.5 \\
\hline Minimum & 3 & 1 \\
\hline Maximum & 59 & 8 \\
\hline
\end{tabular}

Fluency refers to the number of value propositions within a video and flexibility refers to the number of different categories of value propositions within a video (Table 3). Both of these two dimensions are high in the analysed YouTube videos: in general, the impression given is that the destinations often try to persuade with almost as many reasons to visit a specific destination as they can think of. In each video, we counted all sequences or visuals that presents value propositions (fluency) and sorted them by categories (flexibility) and then counted the number of categories of value propositions.

Table 3. Main thematic types of YouTube destination branding videos $(\mathrm{N}=61)$.

\begin{tabular}{ccc}
\hline Content Video Type & Frequency & $\%$ \\
\hline Emotions & 31 & 51 \\
\hline Heritage & 16 & 26 \\
\hline Activities & 9 & 15 \\
\hline Mixed & 5 & 8 \\
\hline Total & 61 & 100 \\
\hline
\end{tabular}

On average, the videos used a very large number of value propositions within a video-The average fluency of a video was 23.5 sequences. Similarly, flexibility or the number of categories of value propositions was very high: on average five categories were included in a video. Within the relatively short time span (length of most videos is 1 to 3 minutes) the video producers thus generally tried to convince the viewers to visit the destination with at least eight different categories of reasons to visit a specific destination. In other words, they strived to represent the high diversity of their destination and the many different activities a visitor can engage in.

This indicates the inherent complexity of destination marketing in relation to other types of marketing. As Fyall and Garrod [49] point out "destinations are notoriously difficult to manage due to the complex systems of stakeholders". Destinations as "products" include extreme diversity and one of the most important challenges is to balance between complexity and simplicity. On the one hand the DMOs need to secure the various tourism 
stakeholders' interests to be represented by the national destination marketing, while on the other they need to simplify the value propositions to a singular message that is relevant to the targeted customer that the tourists will recognise and remember as unique.

This furthermore reveals an inherent paradox of the analysed promotional videos: in striving to be different by enumerating various reasons on why to visit a destination, they become very similar. So similar in fact, that we can identify three main thematic types of destination promotional videos: (a) videos with a focus on representing tourists' emotional states (e.g., happiness, joy, relaxation), (b) videos with a focus on natural or cultural heritage (e.g., waterfalls, landscape, architecture) (c) videos with a focus on tourists' activities (e.g., sports, sightseeing). In Table 3, we can see how common each of the three types were.

The majority of videos were dominated by close-up visuals of tourists' emotional states: well-being, pleasure and remembering or dreaming about the destination (51\%). An example is the video of Ecuador, where the main character claims, that "Ecuador is all you need", that "there is love at every turn" (Figure 1).

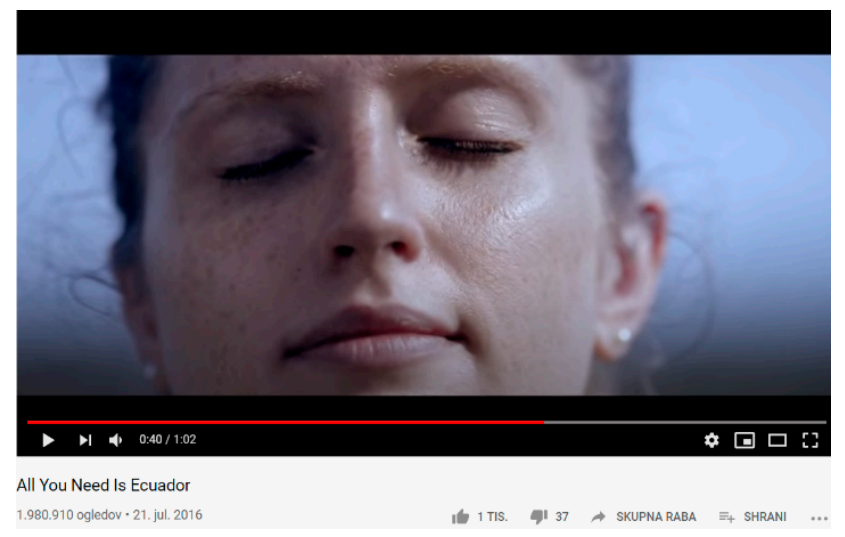

Figure 1. Focus on well-being and relaxation-Video Ecuador [50].

The second most common thematic type (26\%) was videos with a focus on destination's natural or cultural heritage, where they represent material and not on human characters. An example is the Armenian video, where they emphasize Armenia's cultural heritage by showing the natural landscape, churches, traditional food and music (Figure 2).

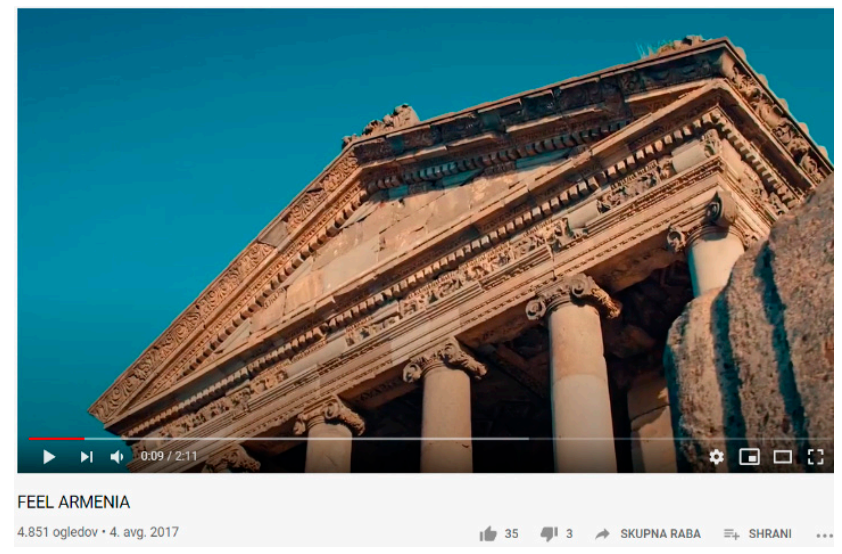

Figure 2. Focus on cultural heritage-Video Armenia [51].

Finally, in $15 \%$ of the videos, the emphasis was placed on showing the activities that tourists can perform at the destination. Mostly this includes sports or sightseeing. For example, in a video of Austria, the video includes representations of rowing on a lake, picking plants, hiking and cycling (Figure 3). 


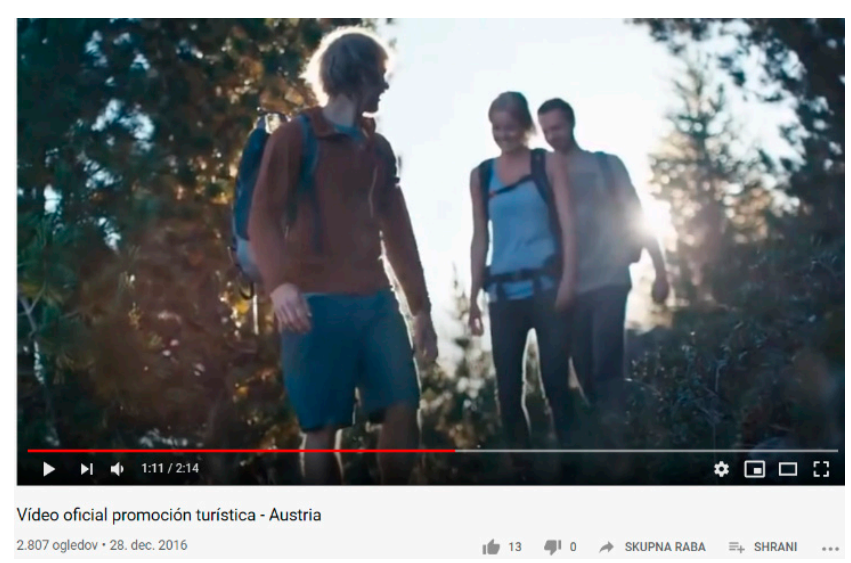

Figure 3. Focus on activities, hiking-Austria [52].

In some videos (Mixed: $8 \%$ ) it was not possible to determine the main theme, as the presentation of the destination was presented through a mix of two or three themes. An important example here would be the case of Indonesia since this was the video that in the end received the UNWTO competition award rewarded by both the jury and the viewers. The video's main themes activities (Figure 4) and emotions (Figure 5) were approximately equally mixed. The accompanying musical background of "What a wonderful world" [53] emphasizes the intact nature that tourists can experience and invites the viewer to daydream about the destination. The fact that the awarding video was one of the videos that did not belong to any of the three main thematic types might be an important confirmation that the way forward in creative destination promotion is in stepping outside of the typical, common thematic approaches.

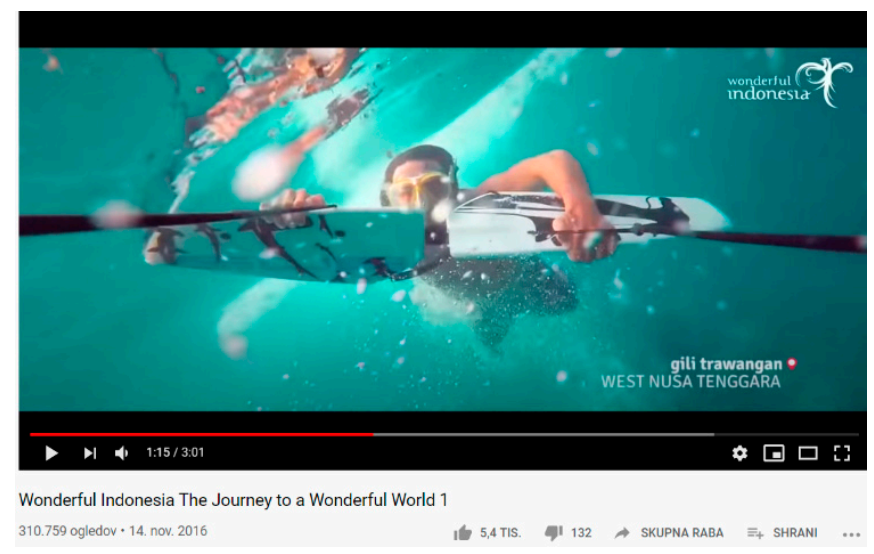

Figure 4. Focus on activities in nature-Indonesia [54].

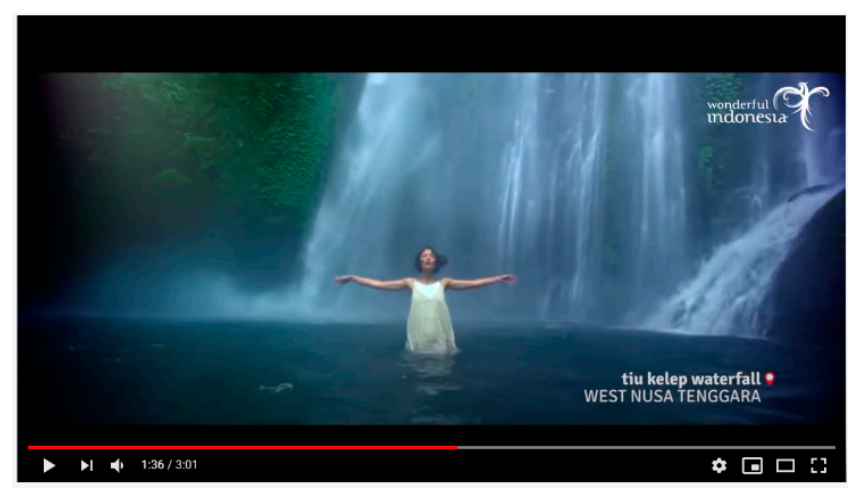

Wonderful Indonesia The Journey to a Wonderful World 1

310.759 ogledov $\cdot 14$. nov. 2016

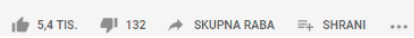

Figure 5. Focus on emotions and well-being-Indonesia [54]. 
Similar to results of Uşaklı et al. [25] who analysed the themes in social media use of 50 European national DMOs, the analysis here showed that the most common categories of value propositions were visuals of tourists performing generic, common tourism activities (such as sightseeing, visiting museums, hiking): $84 \%$ of videos included at least one such sequence, with the average being 5.4 per video (see Table 4 ).

Table 4. Percentages of sequences belonging to each category of value propositions.

\begin{tabular}{cccccccccc}
\hline & \multicolumn{7}{c}{ Percentages of Sequences per Category } & & \\
\cline { 2 - 9 } & $\begin{array}{c}\text { General Tourism } \\
\text { Activities }\end{array}$ & Nature & $\begin{array}{c}\text { Cultural } \\
\text { Heritage }\end{array}$ & Fun/Dance & $\begin{array}{c}\text { Activities } \\
\text { with Hosts }\end{array}$ & Senses & Food & Music \\
\hline$\%$ of videos * & $84 \%$ & $77 \%$ & $72 \%$ & $72 \%$ & $54 \%$ & $30 \%$ & $6 \%$ & $3 \%$ \\
\hline Mean & 5.4 & 4.2 & 3.0 & 2.2 & 1.6 & 0.7 & 0.4 & 0.2 \\
\hline $\begin{array}{c}\text { Stdandard } \\
\text { Deviation }\end{array}$ & 4.0 & 3.7 & 3.4 & 2.3 & 2.4 & 1.4 & 1.1 \\
\hline Maximum & 17 & 13 & 12 & 9 & 12 & 6 & 5 \\
\hline
\end{tabular}

The second most common type of value propositions were stunning visual representations of the destination's nature (no people included in the visuals): $77 \%$ of videos included at least one such sequence while on average they were included 4.2 times per video. Representations of cultural heritage (stunning visuals of, for example, architecture) were the third most common element, with $72 \%$ of videos including at least one such visual sequence, the average being three. The fourth most common type of value propositions were representations of tourists having fun and/or dancing, followed by activities representing tourists-Hosts interactions. A third of the videos included in-depth visual representations of tourists enjoying their senses (e.g., a close-up of a person smelling herbs and flowers). Other two categories were minor in extent: close-ups of local cuisine or music (no people included).

\subsection{Originality: If Each and Every Destination Is Unique How Can One Stand Out?}

Originality represents ideas and elements that are uncommon, rare or surprising, remote, clever [6,55] and are unique solutions to a problem [56]. These original ideas should also be appropriate considering the aim $[57,58]$. Originality is a mandatory element if we want to ensure creativity. If something is not unusual, new or unique, it is usual or conventional. Ideas and products that are purely original can also be very useless [59], thus originality also needs to include meaningfulness.

When we attempted to analyse the third dimension of creativity: originality, operationalized as the number of sequences showing value propositions that are highly infrequent/unique to a specific destination, we encountered a specific problem that at first seemed only a "measurement" dilemma: the coders could not agree on which sequences would be original. After thoughtful deliberation, however, we realized this was not the problem of measurement but highlighted the essence of the problem of creative visual advertising in destination branding.

To illustrate the dilemma: one of the common sequences in the videos was a video representation of a waterfall. This means that including a waterfall is not original since most destinations strive to represent waterfalls. On the other hand, this specific waterfall is only one in the world, albeit not necessarily one of a kind. What the DMOs try to achieve is to represent the specific waterfall as stunningly as possible in order to try to convince the viewer that this waterfall is truly one of a kind. This also means that originality is extremely difficult to analyse via identifying unique value propositions since, in a way, all of them are unique. To illustrate, there can be no doubt that there are after all only one 
Victoria Falls in the world, as they appear in the video of Zambia. However, the same can be argued for the Tiu Kelep Waterfall in West Nusa Tenggara as it appears in the video of Indonesia: although much less known and recognisable it is still unique since there is only one in the world.

The quest for originality in the analysed videos reveals the quest for the "holy grail" of destination promotion: what Pearce [60] terms "intrinsic impact". This refers to the unadorned power of places and settings to capture visitor attention and evoke strong emotional responses. As Pearce [60] warns, "often these places are asked to do too much: to affect the viewer without explanation and without interpretation". Similarly, we can argue that often the visual promotion of a destination asks too much from the viewer: to be able to recognise the uniqueness of a waterfall amongst all other promoted waterfalls. This means that the video producers usually need to look for ways to stand out and be different in other means. Here we turn to the fourth "classical" dimension of creativity: elaboration.

\subsection{Elaboration: Tell Me a (Funny) Story}

Elaboration as defined originally is the extent of detail in the ideas [41]. Later analyses included measures of one's imagination whereby participants were instructed to imagine everything they can think of about an event in as much detail as possible, including actions, people, and feelings [61]. In other words, broadly understood, participants were asked to indulge in storytelling. Ang and Low [43] identified emotional content as one of the dimensions of advertisement creativity. Smith et al. [44] identified four dimensions that can broadly be understood as extending the original concept of elaboration: (a) elaboration: present with ads that include unexpected details, or finish and extend basic ideas so they become more intricate, complicated, or sophisticated; (b) synthesis: present with ads that combine, connect, or blend normally unrelated objects or ideas; (c) artistic value: present with ads that contain artistic verbal impressions or attractive colors or shapes; and (d) imagination: ads that help consumers form vivid mental images, or make something unreal come to life.

We operationalised elaboration as the extent of detail value propositions are presented with. Here we first analysed the videos qualitatively, as a whole in order to identify what are the approaches in the analysed destination branding towards the elaboration features of a promotional ad. The analysis identified two main approaches that are the extremes on the same dimension: storytelling versus collage.

Storytelling in destination branding is a concept that has a very broad meaning, as the process of storytelling involves not only sharing the story with listeners but also the design of the story and all the details of its content, which must be designed and presented to attract listeners [62]. Moin, Hosany and O'Brien [63] point out that storytelling in DMO's promotional videos is still in its infancy, potentially causing a massive loss for the tourism industry. Fog, Budtz and Yakaboylu [64] identified four elements essential for building a story in branding: (a) message, (b) conflict, (c) characters and (d) the chronology of events. The analysis of our sample showed that three of these story elements were included in the storytelling videos, the fourth: conflict, however, was completely absent. We explain this primarily by the fact that destinations do not want to advertise that something negative can happen or go wrong and thus look only for very positive or harmonious story plots. Consequently, we have labelled as story those videos that meet the broader definition of Deighton, Romer, and McQueen [65] who state that the chronological order of a story and the protagonist are the main elements that can be labelled as a story.

Our research confirms the argument of Moin, Hosany and O'Brien [63] that storytelling in destination brand promotional videos is still in its infancy. Only $15 \%$ of the analysed videos (Table 5) included clear storytelling elements: following one main protagonist or a few protagonists in their sequences of events. Almost a third of the videos (26\%) are videos where one of the three elements of storytelling can be detected: most often the main character is repeatedly shown in several sequences that are, however, not connected into a chain of events and are thus not a proper story (Table 5). 
Table 5. Storytelling versus collage in destination brand promotion videos, $\mathrm{N}=61$.

\begin{tabular}{ccc}
\hline & Frequency & $\%$ \\
\hline Storytelling & 9 & 15 \\
\hline One or two storytelling elements present & 16 & 26 \\
\hline Collage & 16 & 26 \\
\hline Other or undefined & 5 & 8 \\
\hline Total & 61 & 100 \\
\hline
\end{tabular}

Storytelling in promotion has an important added value: it evokes emotions and accentuates the experiential elements [66]. We claim here that it is an important indicator of creativity in destination brand marketing via extending the dimension of elaboration (at least for now when it is still rather uncommon). On the other extreme, opposite to storytelling is what we term here as "collage": a mix of different thematic sequences with no story plot or storytelling elements. In collage, we cannot determine the main character, and there is no sequence of events. Through the approach of a collage, the DMO's desire to show as much as the destination has to offer as they can: reflecting the high flexibility and fluency of the videos identified earlier in Table 2.

The collage as a subgenre of destination brand promotional videos is an equivalent of so called "lists" [67] or "factual ads" [68] that provide direct descriptions of product features and benefits. Compared to storytelling approaches, the "lists" have been showed to be less effective forms of promotion than storytelling, for example in affective reactions, ad attitudes and purchase intentions [67] and ad message involvement and subsequent product evaluations [68]. The reasons lie primarily in the fact that these types of advertisements do not involve characters for a long enough time for the audiences to develop an emotional involvement. Additionally, they represent a greater repetition and thus manage less successfully to keep the audience's attention.

While storytelling is one of the clearest ways for a destination brand promotional video to stand out, another similarly poignant way of inclusion of elaboration as the dimension of creativity is using humor. Similarly to storytelling, humor too has been recognised for a long time as an effective means to gain audiences' attention in advertising [69]. PorresGuerrero and Foronda-Robles [70] claim that the use of humor in tourism marketing is a strategy to promote commitment, loyalty and the uniqueness of the destination. Humor is thought to have a more significant impact on product advertising because it is easier to assess these as experiences [71]. Additionally, humor is often the one that attracts the attention of less attentive viewers [72].

Sternthal and Craig [73] explain that the definition of humor requires an examination of responses elicited by recognizable stimuli. Humor is something that connects, and laughter is a key part in maintaining well-being in people. Advertisements by themselves are often considered as an annoying disturbance and they are better accepted if they make the viewer or listener smile [7]. Porres-Guerrero and Foronda-Robles [70] claim that the use of humor in tourism marketing is a strategy to promote commitment, loyalty and the uniqueness of the destination. However, we cannot claim that humor will always be successful or that this will be the only way to connect a brand with the viewer. The key to its success is proper use, which can be tricky as there is a danger that not everyone perceives humor in the same light, so it is more important to use the appropriate type of humor as well $[7,69]$.

Regarding humor in advertising, research shows that male gender is generally more in favor of humorous ads than the female gender [74]. The perception of humor in advertisements is also said to be influenced by the humorous orientation of the individual, which affects his response and the likeability of the ad. Very successful are commercials that evoke a feeling of warmth in individuals and are highly humorous [69]. Buijzen and Valkenburg [75] found that seven different types of humor appear in video ads, which can 
have different effects: (a) clownish humor; the simplest type of humor that involves funny moving hands and feet, (b) surprise: considered a low level of humor, contains sudden changes in concepts and images, (c) slapstick: a high level of humor where it's about unfriendly humor and "a physical pie-in-the-face type of humor", (d) misunderstanding: a relatively low level of humor that reflects laughing at others, ignorance, or disappointment, (e) irony: sarcasm and puns, (f) satire: mocking a famous person or situation, and (g) parody: is a more complex type of humor that requires knowledge and a special media style or genre that is parodied. In our analysis we counted a video as including humor if it included at least one of the seven types of humor identified by Buijzen and Valkenburg [75].

In Table 6 we can see that $16.4 \%$ of the videos included some elements of humor. As an example, we can highlight the video of Switzerland in the analysed sample (Figure 6), where they use slapstick type of humor to present the main character, who convinces people that he can master acrobatic skiing, even though he hired a professional acrobatic skier in same clothes that took pictures instead of him.

Table 6. Inclusion of humor in destination brand promotion videos, $\mathrm{N}=61$.

\begin{tabular}{ccc}
\hline & Frequency & $\%$ \\
\hline No & 51 & 83.6 \\
\hline Yes & 10 & 16.4 \\
\hline Total & 61 & 100 \\
\hline
\end{tabular}

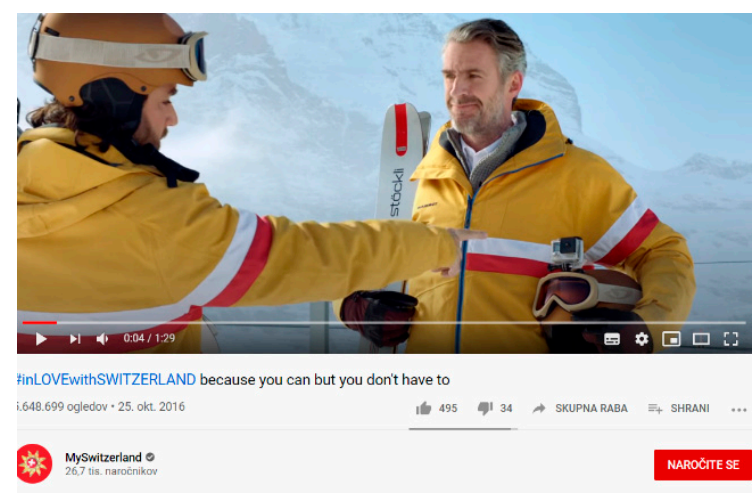

Figure 6. Focus on humor [76].

\section{Conclusions}

The present analysis builds on an important assumption: that the videos included in the UNWTO Tourism Video Competition (2017) [46] were the most original and creative advertisements that the DMO's around the world had to offer at the time. By selecting the competition videos, the present study consequently includes the limitation of analysing only a specific purposefully selected sample, thus not including other types of YouTube destination branding activities. Another important limitation is the primary quantitative nature of the research with the aim of categorising and "putting in boxes" indicators of creativity which is in itself a concept that is inherently highly difficult to analyse in a standardised manner. Third, the analysis focused on videos yet included textual transcriptions of "what was seen" in order to ease the analysis-By itself this then limits the analysis primarily on the elements of thematic content and did not include other possible visual elements of creativity (e.g., camera angle, color palette etc.). All of these limitations thus point to the directions for further research. Having said this, the present analysis nevertheless reveals issues important both for future studies and for destination branding practitioners.

First, the study reveals the inherent complexity of destination marketing in relation to other types of marketing since destinations as "products" include extreme diversity. The most important challenge of destination branding is thus to simplify this diversity into 
easy to remember messages that the tourists will recognise as unique. The analysis showed that most of the time the DMOs attempt to persuade by presenting destination diversity with as many different value propositions as possible. However, in striving to be different by enumerating various reasons as to why to visit a destination, they become very similar. They mostly focus on representing tourists' emotional states, natural or cultural heritage or tourists' activities.

Representing the diversity of a destination, furthermore, leads to a high prominence of what we termed here as "collage" videos: a mix of different thematic sequences, similar to "lists" [67] or "factual ads" [68] that provide direct descriptions of product features and benefits. Compared to storytelling approaches, the "lists" have been showed to be less effective forms of promotion $[67,68]$ since these types of advertisements do not involve characters for a long enough time for the audiences to develop an emotional involvement. Additionally, they represent a greater repetition and thus mange less successfully to keep the audience's attention.

Third, the analysis reveals the inherent problem of originality when branding destinations: each destination is unique in itself. However, this uniqueness in the sea of other uniqueness paradoxically means it is very difficult to stand out. Often the visual promotion of a destination asks too much both from the viewer and their destinations: to be able to recognise the uniqueness of for example a waterfall amongst all other promoted waterfalls or that the destination visuals have an intrinsic impact by themselves. This means that the video producers usually need to look for ways to stand out and be different in other means, not only by what they represent within the visuals. The analysis showed that such means are primarily storytelling and the inclusion of humor, often combined within the same video. When using storytelling, it is recommended to use the main character or characters that appear throughout the video and the visible course of the story. Storytelling and humor serve the function of positive emotional build-up, attracting attention and serve memorability of the video; both are an effective means of advertising by past research. Using stories in representing a destination has a positive effect on encouraging tourists to visit presented destination [77]. Additionally, the use of humor in advertising promotes a positive effect, awareness, and attracts the attention of the advertised [78]. For storytelling and humor, we can claim that they are original approaches in YouTube destination branding since they were rarely present within this selection of "the best of the best" videos.

As such, storytelling and humor are important future directions of destination branding in their quest for creativity. Additionally, a third element was identified, although not analysed in the present research due to the focus on thematic analysis: artistic expression. Defined crudely by Smith et al. [44] as present with ads that contain artistic verbal impressions or attractive colors or shapes this was highly included in the analysed videos and deserves future attention, potentially including experts from the fields of arts and visual communication.

To conclude, the analysis showed that while following the aim to present the diversity of a destination, the analysed destination branding videos paradoxically became a collection of similar visual images and thus failed to contribute to the differentiation of the destination brand. In the future post-COVID era when tourism will try to rebound and hopefully also build more sustainable practices, the competition in destination branding will be extremely harsh. DMOs will have to show even greater creativity in addressing both domestic and foreign travellers. We expect YouTube and visual communication to continue to play a vital role in reaching the target audiences, especially since these will most likely be younger travellers who are more often the users of channels such as YouTube. The results show that future advice to practitioners of destination marketing for YouTube is to go beyond the typical "collage" genre of a destination marketing video and focus more on storytelling, humor and especially the most difficult step in the destination marketing: strategically focusing on the smaller number of specifics that differentiate a destination rather than on the multitude of experiences. 
Author Contributions: Conceptualization, T.A. and M.T.; methodology, T.A. and M.T.; formal analysis, T.A.; data curation, T.A. and M.T.; writing, T.A. and M.T.; project administration, T.A.; funding acquisition, T.A. and M.T. All authors have read and agreed to the published version of the manuscript.

Funding: This research received no external funding.

Institutional Review Board Statement: Not applicable.

Informed Consent Statement: Not applicable.

Data Availability Statement: Publicly available datasets were analyzed in this study.

Conflicts of Interest: The authors declare no conflict of interest.

\section{References}

1. Richards, G.; Wilson, J. Developing creativity in tourist experiences: A solution to the serial reproduction of culture? Tour. Manag. 2006, 27, 1209-1223. [CrossRef]

2. Richards, G. Creativity and tourism: The state of the art. Ann. Tour. Res. 2011, 38, 1225-1253. [CrossRef]

3. Baack, D.W.; Wilson, R.T.; Van Dessel, M.M.; Patti, C.H. Advertising to businesses: Does creativity matter? Ind. Mark. Manag. 2016, 55, 169-177. [CrossRef]

4. El-Murad, J.; West, D.C. The Definition and Measurement of Creativity: What Do We Know? J. Advert. Res. 2004, 44, 188-201. [CrossRef]

5. Yang, X.; Smith, R.E. Beyond Attention Effects: Modeling the Persuasive and Emotional Effects of Advertising Creativity. Mark. Sci. 2009, 28, 935-949. [CrossRef]

6. Reinartz, W.; Saffert, P. Creativity in advertising: When it works and when it doesn't. Harv. Bus. Rev. $2013,91,106-112$.

7. Andrews, J. It's Funny You Should Ask: An Examination of Professionals' Perceptions of the Use of Humor in Advertising. Master's Thesis, Faculty of the Graduate School, University of Missouri-Columbia, Columbia, MO, USA, 2019.

8. Turnšek, M.; Janecek, P. “America First, the Netherlands Second” on YouTube: "spoofing” destination marketing with political satire. Eur. J. Humour Res. 2019, 7, 26-45. [CrossRef]

9. Bex, T. The Genre of Advertising. Rev. Belg. Philol. D'histoire 1993, 71, 719-732. [CrossRef]

10. Pike, S.D.; Page, S.J. Destination Marketing Organizations and destination marketing: A narrative analysis of the literature. Tour. Manag. 2014, 41, 202-227. [CrossRef]

11. Fyall, A.; Garrod, B.J.; Wang, Y. Destination collaboration: A critical review of theoretical approaches to a multi-dimensional phenomenon. J. Destin. Mark. Manag. 2012, 1, 10-26. [CrossRef]

12. Morrison, A. Destination management and destination marketing: The platform for excellence in tourism destinations. Tour. Trib. 2013, 28, 6-9.

13. Sotiriadis, M.; Shen, S. The contribution of partnership and branding to destination management in a globalized context: The case of the UNWTO Silk Road Programme. J. Tour. Herit. Serv. Mark. 2017, 3, 8-16.

14. Perrin, A. Social Media Usage; Pew Research Center: Washington, DC, USA, 2015; pp. 52-68.

15. Zeng, B.; Gerritsen, R. What do we know about social media in tourism? A review. Tour. Manag. Perspect. 2014, 10, 27-36. [CrossRef]

16. Leung, D.; Law, R.; Van Hoof, H.; Buhalis, D. Social Media in Tourism and Hospitality: A Literature Review. J. Travel Tour. Mark. 2013, 30, 3-22. [CrossRef]

17. Tsimonis, G.; Dimitriadis, S. Brand strategies in social media. Mark. Intell. Plan. 2014, 32, 328-344. [CrossRef]

18. Hays, S.; Page, S.J.; Buhalis, D. Social media as a destination marketing tool: Its use by national tourism organisations. Curr. Issues Tour. 2013, 16, 211-239. [CrossRef]

19. Hutter, K.; Hautz, J.; Dennhardt, S.; Füller, J. The impact of user interactions in social media on brand awareness and purchase intention: The case of MINI on Facebook. J. Prod. Brand Manag. 2013, 22, 342-351. [CrossRef]

20. Stojanovic, I.; Andreu, L.; Curras-Perez, R. Effects of the intensity of use of social media on brand equity: An empirical study in a tourist destination. Eur. J. Manag. Bus. Econ. 2018, 27, 83-100. [CrossRef]

21. Mehmood, I.; Sajjad, M.; Rho, S.; Baik, S.W. Divide-and-conquer based summarization framework for extracting affective video content. Neurocomputing 2016, 174, 393-403. [CrossRef]

22. Babin, L.A.; Burns, A.C. Effects of Print Ad Pictures and Copy Containing Instructions to Imagine on Mental Imagery That Mediates Attitudes. J. Advert. 1997, 26, 33-44. [CrossRef]

23. Celikkale, B.; Erdem, A.; Erdem, E. Visual Attention-Driven Spatial Pooling for Image Memorability. In Proceedings of the 2013 IEEE Conference on Computer Vision and Pattern Recognition Workshops, Portland, OR, USA, 23-28 June 2013 ; pp. $976-983$.

24. Dehghani, M.; Niaki, M.K.; Ramezani, I.; Sali, R. Evaluating the influence of YouTube advertising for attraction of young customers. Comput. Hum. Behav. 2016, 59, 165-172. [CrossRef]

25. Uşakl1, A.; Koç, B.; Sönmez, S. How 'social' are destinations? Examining European DMO social media usage. J. Destin. Mark. Manag. 2017, 6, 136-149. [CrossRef] 
26. Turnšek Hančič, T.; Kurež, B.; Brumen, B.; Rosi, M.; Rangus, M. The political economy of social media: What does it mean for tourism? The case of YouTube. Acad. Tur. 2013, 6, 17-75.

27. Huang, J.; Su, S.; Zhou, L.; Liu, X. Attitude toward the viral ad: Expanding traditional advertising models to interactive advertising. J. Interact. Mark. 2013, 27, 36-46. [CrossRef]

28. Huertas, A.; Míguez-González, M.-I.; Lozano-Monterrubio, N. YouTube usage by Spanish tourist destinations as a tool to communicate their identities and brands. J. Brand Manag. 2017, 24, 211-229. [CrossRef]

29. Algie, J.; Mead, N. Fun ways to engage with rail safety through the dumb ways to die social marketing campaign. In Customer Relationship Management; Springer Science and Business Media LLC: Berlin/Heidelberg, Germany, 2019; pp. 93-110.

30. Jenkins, H.; Green, J.; Hartley, J.; Burgess, J. YouTube: Online Video and Participatory Culture; Polity Press: Cambridge, MA, USA, 2013.

31. Molnár, V. Reframing public space through digital mobilization: Flash mobs and contemporary urban youth culture. Space Cult. 2014, 17, 43-58. [CrossRef]

32. Shifman, L. An anatomy of a YouTube meme. New Media Soc. 2012, 14, 187-203. [CrossRef]

33. Torrance, E.P. Scientific views of creativity and factors affecting its growth. Daedalus 1965, 94, 663-681.

34. Fletcher, W. The Management of Creativity. Int. J. Advert. 1990, 9, 1-37. [CrossRef]

35. Young, A.P. Visual methodologies: An introduction to the interpretation of visual methods (2nd ed.). Libr. Inf. Sci. Res. 2009, 31, 72. [CrossRef]

36. Jordanous, A. Stepping back to progress forwards: Setting standards for meta- evaluation of computational creativity. In Proceedings of the 5th International Conference on Computational Creativity, Association for Computational Creativity, Ljubljana, Slovenia, 10-13 June 2014; pp. 129-136.

37. Lubart, T.I. 17 Creativity across cultures. In Handbook of Creativity; Cambridge University Press: Cambridge, UK, 1999; pp. 339-350.

38. Krippendorff, K. Content Analysis: An Introduction to Its Methodology; Sage: London, UK, 2004.

39. Lamb, C.; Brown, D.G.; Clarke, C.L. Evaluating computational creativity: An interdisciplinary tutorial. Acm Comput. Surv. (Csur) 2018, 51, 1-34. [CrossRef]

40. Hekkert, P.P.; Snelders, H.D.; Van Wieringen, P.C.W. 'Most advanced, yet acceptable': Typicality and novelty as joint predictors of aesthetic preference in industrial design. Br. J. Psychol. 2003, 94, 111-124. [CrossRef] [PubMed]

41. Guilford, J.P. The structure of intellect. Psychol. Bull. 1956, 53, 267. [CrossRef] [PubMed]

42. Smith, R.E.; Yang, X. Toward a general theory of creativity in advertising: Examining the role of divergence. Mark. Theory 2004, 4, 31-58. [CrossRef]

43. Ang, S.H.; Low, S.Y.M. Exploring the dimensions of ad creativity. Psychol. Mark. 2000, 17, 835-854. [CrossRef]

44. Smith, R.E.; MacKenzie, S.B.; Yang, X.; Buchholz, L.M.; Darley, W.K. Modeling the determinants and effects of creativity in advertising. Mark. Sci. 2007, 26, 819-833. [CrossRef]

45. Kübler, R.V.; Proppe, D. Faking or convincing: Why do some advertising campaigns win creativity awards? Bus. Res. 2012, 5, 60-81. [CrossRef]

46. UNWTO. UNWTO Tourism Video Competition Guidelines. Available online: http://lmd.unwto.org/content/unwto-tourismvideo-competition-guidelines (accessed on 15 February 2018).

47. Feel Slovenia. (23 September 2016). Slovenia. Make New Memories. Available online: https://www.youtube.com/watch?v= YZRM1guRKfY (accessed on 28 August 2020).

48. Braun, V.; Clarke, V. Using thematic analysis in psychology. Qual. Res. Psychol. 2006, 3, 77-101. [CrossRef]

49. Fyall, A.; Garrod, B. Destination management: A perspective article. Tour. Rev. 2019, 75, 165-169. [CrossRef]

50. Visit Ecuador and its Galapagos Islands. (21 July 2016). All You Need Is Ecuador. Available online: https://www.youtube.com/ watch? v=mTyhK_-CP64 (accessed on 29 August 2020).

51. State Tourism Committee of Armenia, (4 August 2017). Feel Armenia. Available online: https://www.youtube.com/watch?v= 6kYY6ifan5U (accessed on 28 August 2020).

52. Whale, B. (28 December 2016). Vídeo oficial promoción turística-Austria. Available online: https://www.youtube.com/watch? $\mathrm{v}=\mathrm{JpkHg}$-J_jOs (accessed on 29 August 2020).

53. Weiss, G.D.; Thiele, B.; Armstrong, L. What a Wonderful World; ABC Records: New York City, NY, USA, 1967.

54. Eyan, B. (14 November 2016). Wonderful Indonesia the Journey to a Wonderful World 1. Available online: https://www.youtube. $\mathrm{com} /$ watch? $\mathrm{v}=$ Xws XCeuATy0 (accessed on 30 August 2020).

55. Silvia, P.J.; Winterstein, B.P.; Willse, J.T.; Barona, C.M.; Cram, J.T.; Hess, K.I.; Martinez, J.L.; Richard, C.A. Assessing creativity with divergent thinking tasks: Exploring the reliability and validity of new subjective scoring methods. Psychol. Aesthet. Creat. Arts 2008, 2, 68-85. [CrossRef]

56. Rababah, L.M.; Halim, A.; Mohamed, B.; Jdaitawi, M.T. The level of creativity in English writing among Jordanian secondary school students. Arts Des. Stud. 2013, 10, 25-29.

57. Guilford, J.P. Creativity. Am. Psychol. 1950, 5, 444-454. [CrossRef] [PubMed]

58. Sternberg, R.J.; Lubart, T.I. The Concept of Creativity: Prospects and Paradigms. Handb. Creat. 1998, 1, 3-15. [CrossRef]

59. Runco, M.A.; Jaeger, G.J. The Standard Definition of Creativity. Creat. Res. J. 2012, 24, 92-96. [CrossRef]

60. Hsu, C.H. Tourist behaviour: Themes and conceptual schemes. Ann. Tour. Res. 2006, 33, 874-875. [CrossRef] 
61. Madore, K.P.; Jing, H.G.; Schacter, D.L. Divergent creative thinking in young and older adults: Extending the effects of an episodic specificity induction. Mem. Cogn. 2016, 44, 974-988. [CrossRef]

62. SPIRIT. Zgodbe o Slovenskem Turizmu. 2013. Available online: http://www.slovenia.info/pictures/category/atachments_1/20 14/Zgodbarski_priro\%C3\%84\%C5\%A4nik_-_celoten_31.1_17646.pdf (accessed on 15 February 2018).

63. Moin, S.M.A.; Hosany, S.; O’Brien, J. Storytelling in destination brands' promotional videos. Tour. Manag. Perspect. 2020, 34, 100639. [CrossRef]

64. Fog, K.; Budtz, C.; Yakaboylu, B. Storytelling: Branding in Practice; Samfundslitteratur: Copenhagen, Denmark, 2010.

65. Deighton, J.; Romer, D.; McQueen, J. Using Drama to Persuade. J. Consum. Res. 1989, 16, 335-343. [CrossRef]

66. Simmons, A. The Story Factor: Inspiration, influence, and Persuasion through the Art of Storytelling; Basic Books: New York, NY, USA, 2006.

67. Mattila, A.S. The Role of Narratives in the Advertising of Experiential Services. J. Serv. Res. 2000, 3, 35-45. [CrossRef]

68. Polyorat, K.; Alden, D.L.; Kim, E.S. Impact of narrative versus factual print ad copy on product evaluation: The mediating role of ad message involvement. Psychol. Mark. 2007, 24, 539-554. [CrossRef]

69. Riecken, G.; Hensel, K. Using humor in Advertising: When does it work? South. Bus. Rev. 2020, 37, 27-37.

70. Porres-Guerrero, M.; Foronda-Robles, C. Where is the humour in tourism promotion? An investigation of the "Spain Marks" campaign. Eur. J. Humour Res. 2019, 7, 46-62. [CrossRef]

71. Chiu, H.-C.; Hsieh, Y.-C.; Kuo, Y.-C. How to align your brand stories with your products. J. Retail. 2012, 88, 262-275. [CrossRef]

72. Zhang, Y.; Zinkhan, G.M. Responses to humorous ADS: Does audience involvement matter? J. Advert. 2006, 35, 113-127. [CrossRef]

73. Sternthal, B.; Craig, C.S. Humor in advertising. J. Mark. 1973, 37, 12-18. [CrossRef]

74. Conway, M.; Dubé, L. Humor in persuasion on threatening topics: Effectiveness is a function of audience sex role orientation. Pers. Soc. Psychol. Bull. 2002, 28, 863-873. [CrossRef]

75. Buijzen, M.; Valkenburg, P.M. Developing a typology of humor in audiovisual media. Media Psychol. 2004, 6, 147-167. [CrossRef]

76. MySwitzerland. (25 October 2016). \#inLOVEwithSWITZERLAND Because You Can But You Don't Have to. Available online: https: / / www.youtube.com/watch?v=2AApP13LGcE (accessed on 1 September 2020).

77. Woodside, A.G.; Sood, S.; Miller, K.E. When consumers and brands talk: Storytelling theory and research in psychology and marketing. Psychol. Mark. 2008, 25, 97-145. [CrossRef]

78. Lee, Y.H.; Mason, C. Responses to Information Incongruency in Advertising: The Role of Expectancy, Relevancy, and Humor. J. Consum. Res. 1999, 26, 156-169. [CrossRef] 